OAK RIDGE

NATIONAL LABORATORY

MANAGED BY UT-BATTELLE

FOR THE DEPARTMENT OF ENERGY
Overall Plan for Physics Outlining Steps Necessary for Insertion of the LTA and Operation Using a 1/3 MOX Loaded Core

\author{
A. M. Pavlovichev \\ P. Alexeev \\ I. Levina \\ A. Makhonkov \\ V. Orlov \\ Y. Riabinine \\ Y. A. Styrine
}

Russian Research Center "Kurchatov Institute"

A Russian Contribution to the Fissile Materials Disposition Program

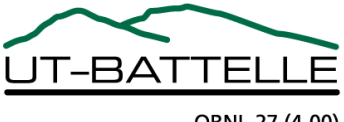




\section{DOCUMENT AVAILABILITY}

Reports produced after January 1, 1996, are generally available free via the U.S. Department of Energy (DOE) Information Bridge.

Web site http://www.osti.gov/bridge

Reports produced before January 1, 1996, may be purchased by members of the public from the following source.

National Technical Information Service

5285 Port Royal Road

Springfield, VA 22161

Telephone 703-605-6000 (1-800-553-6847)

TDD 703-487-4639

Fax 703-605-6900

E-mail info@ntis.fedworld.gov

Web site http://www.ntis.gov/support/ordernowabout.htm

Reports are available to DOE employees, DOE contractors, Energy Technology Data Exchange (ETDE) representatives, and International Nuclear Information System (INIS) representatives from the following source.

Office of Scientific and Technical Information

P.O. Box 62

Oak Ridge, TN 37831

Telephone 865-576-8401

Fax 865-576-5728

E-mail reports@adonis.osti.gov

Web site http://www.osti.gov/contact.html

This report was prepared as an account of work sponsored by an agency of the United States Government. Neither the United States Government nor any agency thereof, nor any of their employees, makes any warranty, express or implied, or assumes any legal liability or responsibility for the accuracy, completeness, or usefulness of any information, apparatus, product, or process disclosed, or represents that its use would not infringe privately owned rights. Reference herein to any specific commercial product, process, or service by trade name, trademark, manufacturer, or otherwise, does not necessarily constitute or imply its endorsement, recommendation, or favoring by the United States Government or any agency thereof. The views and opinions of authors expressed herein do not necessarily state or reflect those of the United States Government or any agency thereof. 
ORNL/SUB/00-85B99398V-1

\title{
OVERALL PLAN FOR PHYSICS OUTLINING STEPS NECESSARY FOR INSERTION OF THE LTA AND OPERATION USING A 1/3 MOX LOADED CORE
}

\author{
A. M. Pavlovichev \\ P. Alexeev \\ I. Levina \\ A. Makhonkov \\ V. Orlov \\ Y. Riabinine \\ Y. A. Styrine
}

Date Published: April 2001

\author{
Prepared by \\ Russian Research Center "Kurchatov Institute" \\ Institute of Nuclear Reactors \\ under subcontract 85B-99398V \\ Funded by \\ Office of Fissile Materials Disposition \\ U.S. Department of Energy \\ Prepared for \\ Computational Physics and Engineering Division \\ OAK RIDGE NATIONAL LABORATORY \\ Oak Ridge, Tennessee 37831 \\ managed by \\ UT-BATTELLE, LLC \\ for the \\ U.S. DEPARTMENT OF ENERGY \\ under contract DE-AC05-00OR22725
}




\title{
Russian Research Center "Kurchatov Institute" \\ Institute of Nuclear Reactors \\ VVER Division
}

Joint U.S. / Russian Project to Update, Verify and Validate Reactor Design/Safety Computer Codes

Associated with Weapons-Grade Plutonium Disposition in VVER Reactors

\section{Overall Plan for Physics Outlining Steps Necessary for Insertion of the LTA and operation using a 1/3 MOX loaded core}

\author{
General Order 85B-99398V
}

Project Manager

A.M.Pavlovichev

Executed by

P.Alexeev

I.Levina

A.Makhonkov V.Orlov

Y.Riabinine

Y.A.Styrine

Moscow 2000 
Physics outlining steps necessary for insertion of the LTA, and operation using a 1/3 MOX loaded core

\section{SUMMARY}

Document issued according to Work Release KI-WR04RTP. P. 00-1 describes physics tasks that are included in the current version of "Roadmap.Level 2" concerning Reactor tasks of Weapon-grade plutonium disposition problem for VVER1000. On this base the objective is to identify the physical tasks in FY2000 and in future as a part of global activities on weapon-grade MOX fuel introduction into VVER-1000. 
Physics outlining steps necessary for insertion of the LTA, and operation using a 1/3 MOX loaded core

\section{CONTENT}

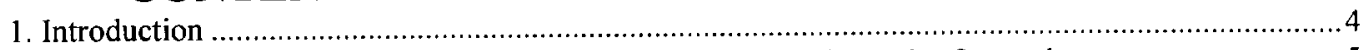

2. Description of blocks in Roadmap-level 2 including neutronics and safety tasks ..........................5

3. Connection of FY2000 (KI-WR04RTP) items with Roadmap-level 2 .................................. 19 


\section{Introduction}

The present work is a part of Joint U.S. / Russian Project with Weapon-Grade Plutonium Disposition in Russian light-water reactors VVER. According to "AGREEMENT BETWEEN THE GOVERNMENT OF THE UNITED STATES OF AMERICA AND THE GOVERNMENT OF THE RUSSIAN FEDERATION CONCERNING THE MANAGEMENT AND DISPOSITION OF PLUTONIUM DESIGNATED AS NO LONGER REQUIRED FOR DEFENSE PURPOSES AND RELATED COOPERATION" signed in the 1 Sept. 2000 reactors VVER-1000 are to be involved in this problem.

"ROADMAP. Level 2" concerning VVER-1000 NPP activities with MOX is being developed by VNIIAES with the participation of specialists of RRC "Kurchatov Institute", OKB "Gidropress", Rosenergoatom and others. The current version of "ROADMAP. Level 2" is based on the scenario named "Variant 1": 4 Balakovo NPP units are involved with the transition from $1 / 3$ to $41 \%$ MOX fuel in core.

This document presents blocks containing physical (neutronics) tasks included in "ROADMAP. Level 2". The most of these tasks is the subject of Work Releases 01, 02, KI-WR04RTP of GENERAL ORDER AGREEMENT 85B-99398V between UT-BATTELLE, LLC and RUSSIAN RESEARCH CENTER KURCHATOV INSTITUTE (RRC KI). On the base of the description presented below the objective is to identify the physical tasks in FY2000 (WR KI-WR04RTP) and in future Work Releases as a part of global activities on weapon-grade MOX fuel introduction into VVER-1000. 


\section{Description of blocks in Roadmap-level 2 including neutronics and safety tasks}

In the Table below the Roadmap-level 2 items, concerning neutronics and reactor safety aspects, are presented. These items demand involving of scientific and engineering personal that participates in neutronics and thermohydraulic project calculations of VVER reactors. 
Russlan Research Center "Kurchatov Insttuts"

Physics outlining steps necessary for insertion of the LTA, and operation using a 1/3 MOX loaded core

\begin{tabular}{|l|l|l|}
\hline Block & Block Name & Description of physical part \\
\hline RX-2 & $\begin{array}{l}\text { Verification of Codes for Neutron Calculations } \\
\text { to Justify/Assess Nuclear Safety of the Reactor }\end{array}$ & $\begin{array}{l}\text { Verify the MCU/ORIGEN-S precision code based on (1) the results of } \\
\text { criticality experiments using VVER uranium fuel, (2) international test } \\
\text { benchmarks and (3) the results of criticality experiments with MOX fuel } \\
\text { conducted in the US and Europe, and (4) calculated benchmarks. } \\
\text { Verify the RRC KI engineering software package (TBC-M / TVS-M, 5VIP7- } \\
\text { A / BIPR7-A and חEPMAK-A/PERMAK-A) based on criticality tests with } \\
\text { uranium fuel, operational data for uranium core VVER reactors, data on } \\
\text { irradiating uranium fuel, and calculated benchmarks. } \\
\text { Modify and verify the 3-D neutron kinetics software packages (HOCTPA } \\
\text { NOSTRA and BhIP8-KH / BIPR8-KN), based on the results of criticality tests } \\
\text { with uranium fuel, operational data, and calculated benchmarks. } \\
\text { Verify the software for calculating fast neutron fluence to the reactor vessel } \\
\text { (software package DOORS with codes DORT, ANISN and libraries of } \\
\text { constants, BUGLE-96 and others). Verify the models and procedures for } \\
\text { calculating the witness standard radiation load (code TORT with libraries of } \\
\text { constants, BUGLE-96 and others). } \\
\text { Verify the RRC KI code for calculating the release of dioxide-fuel fission } \\
\text { products and the migration in the primary loop systems of VVER-type reactors } \\
\text { under standard operating conditions and during design accidents (RELWWER- } \\
\text { 2.0 and LEAK3). Verify MELLOR, CONTAIN, VICTORIA, and ORIGEN } \\
\text { codes for beyond-design accidents. } \\
\text { Modify the methodology on leak-proof check the fuel element cladding }\end{array}$
\end{tabular}


Russian Research Center "Kurchatov Insttute"

Physics outlining steps necessary for insertion of the LTA, and operation using a 1/3 MOX loaded core

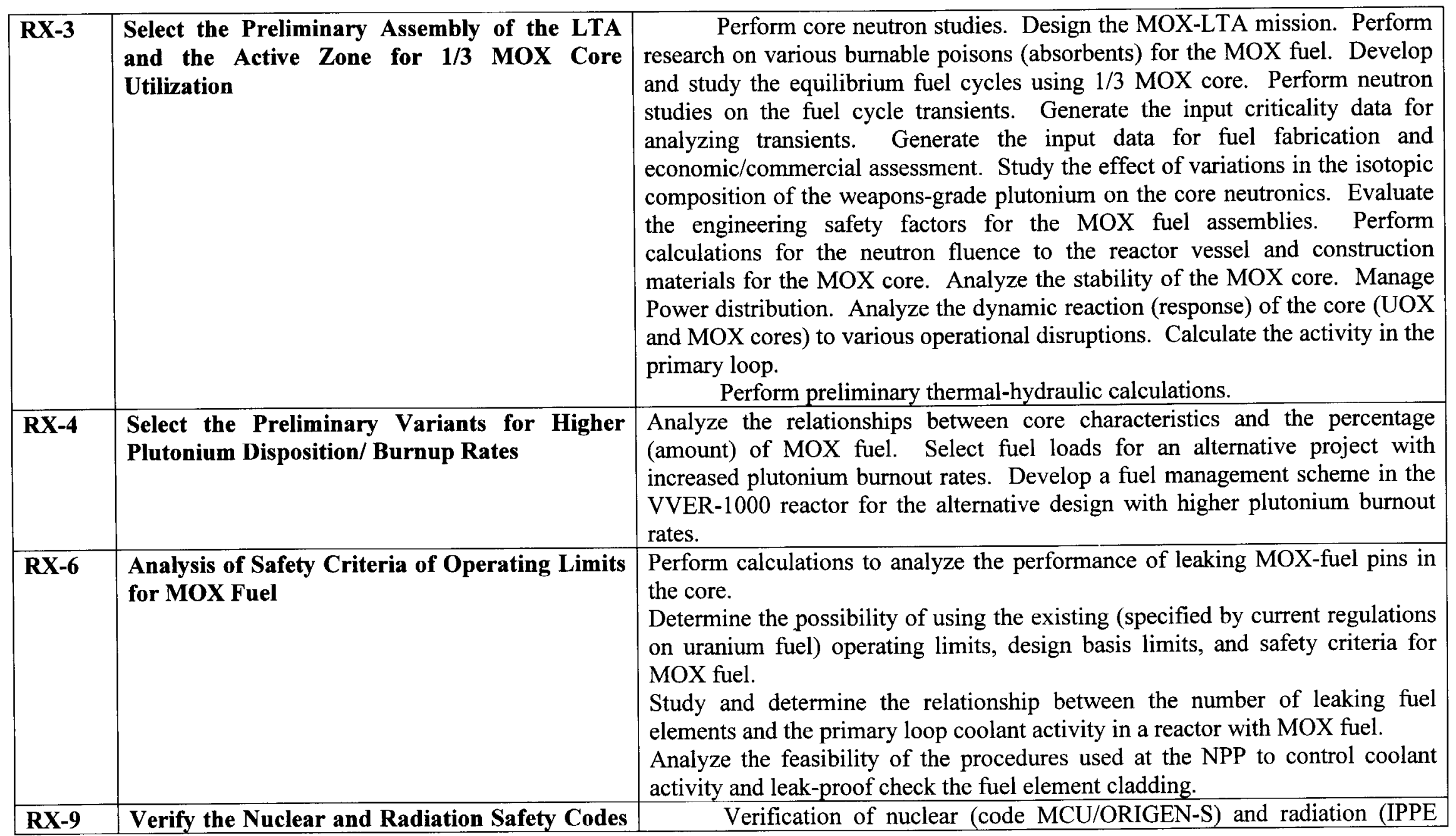


Russian Research Center "Kunchatov Institute"

Physics outlining steps necessary for insertion of the LTA, and operation using a 1/3 MOX loaded core

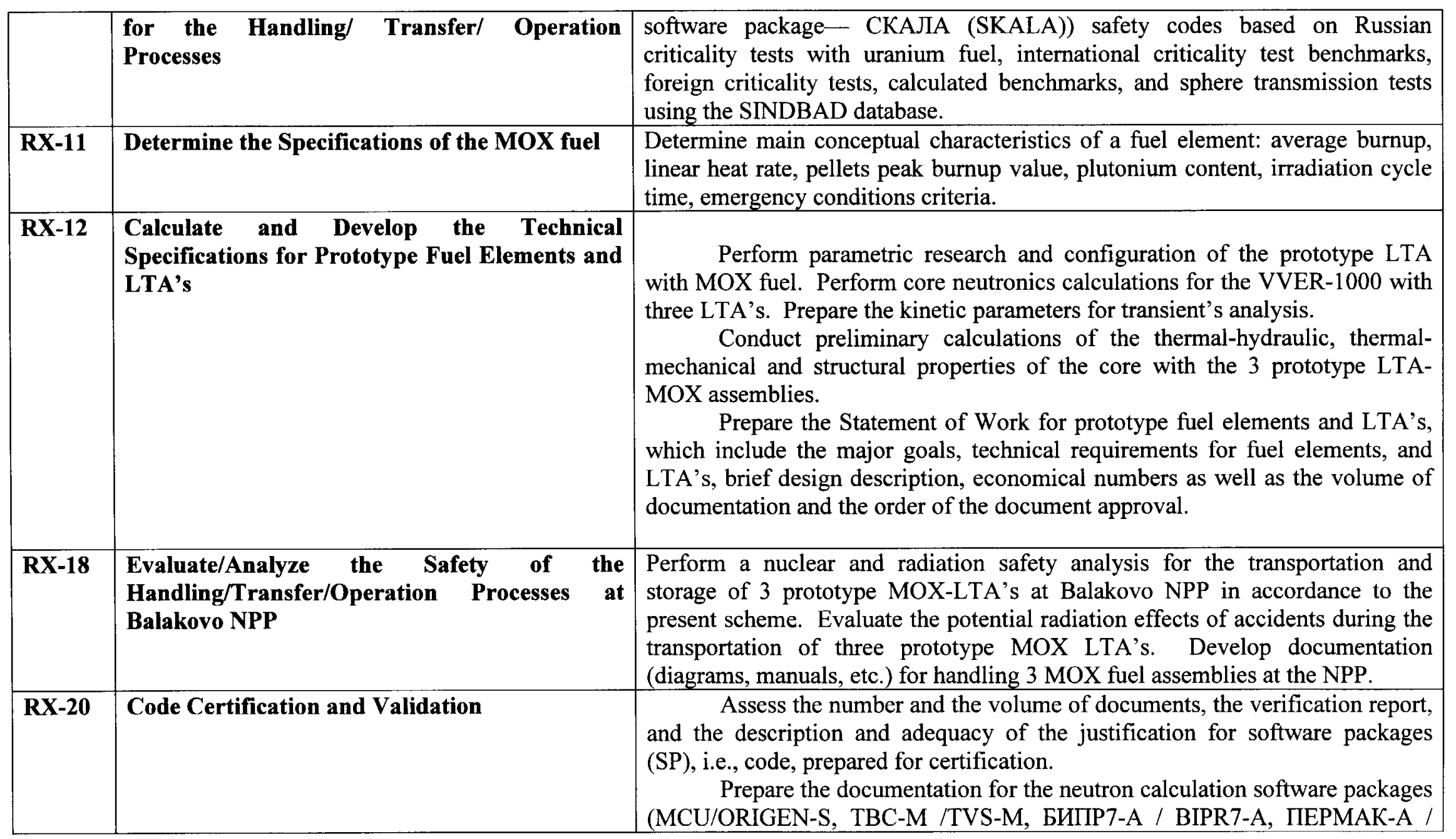


Russian Research Center "Kurchatov Instturte"

Physics outlining steps necessary for insertion of the LTA, and operation using a 1/3 MOX loaded core

\begin{tabular}{|c|c|c|}
\hline & & $\begin{array}{l}\text { PERMAK-A). Send the application to the Certification Commission under } \\
\text { Scientific and Technical Center of GAN of the Russian Federation to obtain the } \\
\text { Certificate. }\end{array}$ \\
\hline RX-24 & $\begin{array}{l}\text { Develop an Addendum to the Primary System } \\
\text { Safety Analysis Report (SAR) for Balakovo } \\
\text { NPP Unit } 4\end{array}$ & $\begin{array}{l}\text { Corrections of SAR statements necessary for safety justification of Balakovo } \\
\text { Unit } 4 \text { operation with } 3 \text { LTAs including: } \\
\text { Neutronics characteristics, } \\
\text { Thermohydraulics characteristics, } \\
\text { Structural characteristics, } \\
\text { Nuclear and radiation safety. } \\
\text { Influence of new and modernized equipment on safety. }\end{array}$ \\
\hline RX-26 & $\begin{array}{l}\text { Select Fuel Loads and Perform Neutron } \\
\text { Calculations for the Placement of Three MOX- } \\
\text { LTA's }\end{array}$ & $\begin{array}{l}\text { Select the fuel load, determine the scope and conduct core neutronics } \\
\text { calculations using the current fuel load as a reference. Analyze and process } \\
\text { operational data from previous reactor feeds. } \\
\text { Develop experimental procedures for determining core neutronics } \\
\text { properties. Develop equivalence criteria for calculations and tests. }\end{array}$ \\
\hline RX-29 & $\begin{array}{l}\text { Perform Balakovo NPP } \\
\text { Training }\end{array}$ & $\begin{array}{l}\text { Provide procedural software to the NPP personnel to perform neutronics } \\
\text { calculations and conduct experimental research in the course of operations with } \\
\text { LTA's. Conduct training of the following personnel involved in the operation } \\
\text { of Unit } 4 \text { in context of operational documentation updates: } \\
\text { Transportation and processing operations; } \\
\text { Physicists and nuclear safety personnel; } \\
\text { Radiation safety personnel; } \\
\text { Security personnel; } \\
\text { Heat engineers }\end{array}$ \\
\hline RX-30 & Safety Analysis & $\begin{array}{l}\text { Perform safety analysis of installing } 3 \text { MOX LTA's into the reactor of } \\
\text { Unit 4, Balakovo NPP. Obtain neutron (flux) characteristics of the core and the } \\
\text { thermal-physical characteristics of the fuel and fuel elements used for } \\
\text { calculating the safety parameters. Determine the safety operation parameters. }\end{array}$ \\
\hline
\end{tabular}


Russian Research Center "Kurchatov Insttute"

Physics outlining steps necessary for insertion of the LTA, and operation using a 1/3 MOX loaded core

\begin{tabular}{|c|c|c|}
\hline & & $\begin{array}{l}\text { Calculate thermal hydraulics of industrial, transient, and emergency (including } \\
\text { reactivity accidents and conservative approximation) modes of reactor } \\
\text { operation. Create different scenarios of operational modes and design accidents } \\
\text { and develop initial data to justify the fuel elements choice. } \\
\text { Calculate the primary loop activity under standard and emergency } \\
\text { operational modes and design accidents. }\end{array}$ \\
\hline RX-34 & $\begin{array}{l}\text { Prepare the Documentation for Licensing the } \\
\text { Irradiation of Three MOX-LTA's }\end{array}$ & $\begin{array}{l}\text { Develop a test operational program for the reactor with } 3 \text { MOX fuel } \\
\text { assemblies. Prepare documentation for licensing the use of fissile materials in } \\
\text { R\&D, which includes the program for testing three prototype MOX-LTA's. } \\
\text { Prepare documentation to make amendments to the licensing terms and } \\
\text { conditions for the operation of Balakovo NPP Unit } 4 \text {. } \\
\text { Provide a preliminary assessment of operational documentation and of } \\
\text { materials justifying safety. }\end{array}$ \\
\hline RX-36 & $\begin{array}{l}\text { Irradiate the Three MOX-LTA's Over a } \\
\text { Three-Year Period }\end{array}$ & $\begin{array}{l}\text { Measure the reactor neutronics (Neutron flux measurements). Measure } \\
\text { the fresh and irradiated fuel characteristics. Develop calculation-based support } \\
\text { of the MOX-LTA's irradiation. Perform data acquisition and data analysis of } \\
\text { the reactor operation. }\end{array}$ \\
\hline
\end{tabular}


Ruasian Research Center "Kurchatov Insttute"

Physics outlining steps necessary for insertion of the LTA, and operation using a 1/3 MOX loaded core

\begin{tabular}{|c|c|c|}
\hline & & $\begin{array}{l}\text { on the irradiation data of } 3 \text { MOX fuel assemblies. } \\
\text { Estimation of documentation specification on verification and its completion for } \\
\text { the codes to be certified. } \\
\text { Prepare certification documentation for the MCU/ORIGEN-S, TBC-M (TVS- } \\
\text { M), БИПР8-KН (BIPR7-A), ПЕPMAK-A (PERMAK-A), IPPE software } \\
\text { package CКАЛА / SKALA, (RELWWER-2.0). Send the application to the } \\
\text { Certification Commission under the Science and Technical Center of GAN of } \\
\text { the Russian Federation to obtain a certificate. }\end{array}$ \\
\hline RX-38 & $\begin{array}{l}\text { Develop an Addendum to the Reactor Facility } \\
\text { Safety Analysis Report }\end{array}$ & $\begin{array}{l}\text { Corrections of SAR statements necessary for safety justification of Balakovo } \\
\text { Units 1-4 operation with } 1 / 3 \text { serial MOX fuel assemblies including: } \\
\text { Neutronics characteristics, } \\
\text { Thermohydraulics characteristics, } \\
\text { Structural characteristics, } \\
\text { Nuclear and radiation safety, } \\
\text { Influence of new and modernized equipment on safety, } \\
\text { Assessment of consequences of beyond design limit accidents. }\end{array}$ \\
\hline RX-39 & $\begin{array}{l}\text { Conduct Experiments Using the Criticality } \\
\text { Testing Bed }\end{array}$ & $\begin{array}{l}\text { Develop a program for conducting research at the (SUPR) test bed } \\
\text { The program will be developed using the analysis of the indeterminacy of the } \\
\text { major characteristics of uranium and MOX cores in VVER-1000 and the } \\
\text { uncertainty analysis of the experimental techniques previously determined by } \\
\text { foreign experiments. } \\
\text { The following characteristics/parameters will be measured: } \\
\text { local micro-fields; } \\
\text { efficiency of fuel and absorber elements and their interference; } \\
\text { neutron and gamma-quantum loss/leakage and their spectrum; } \\
\text { neutron balance in (fuel) cells and LTA's; } \\
\text { spatial kinetics; } \\
\text { statistical analysis of technological limits (margins) for MOX fuel elements; } \\
\text { density and temperature factors of reactivity. }\end{array}$ \\
\hline
\end{tabular}


Russian Research Center "Kunchatov Inattute"

Physics outlining steps necessary for insertion of the LTA, and operation using a 1/3 MOX loaded core

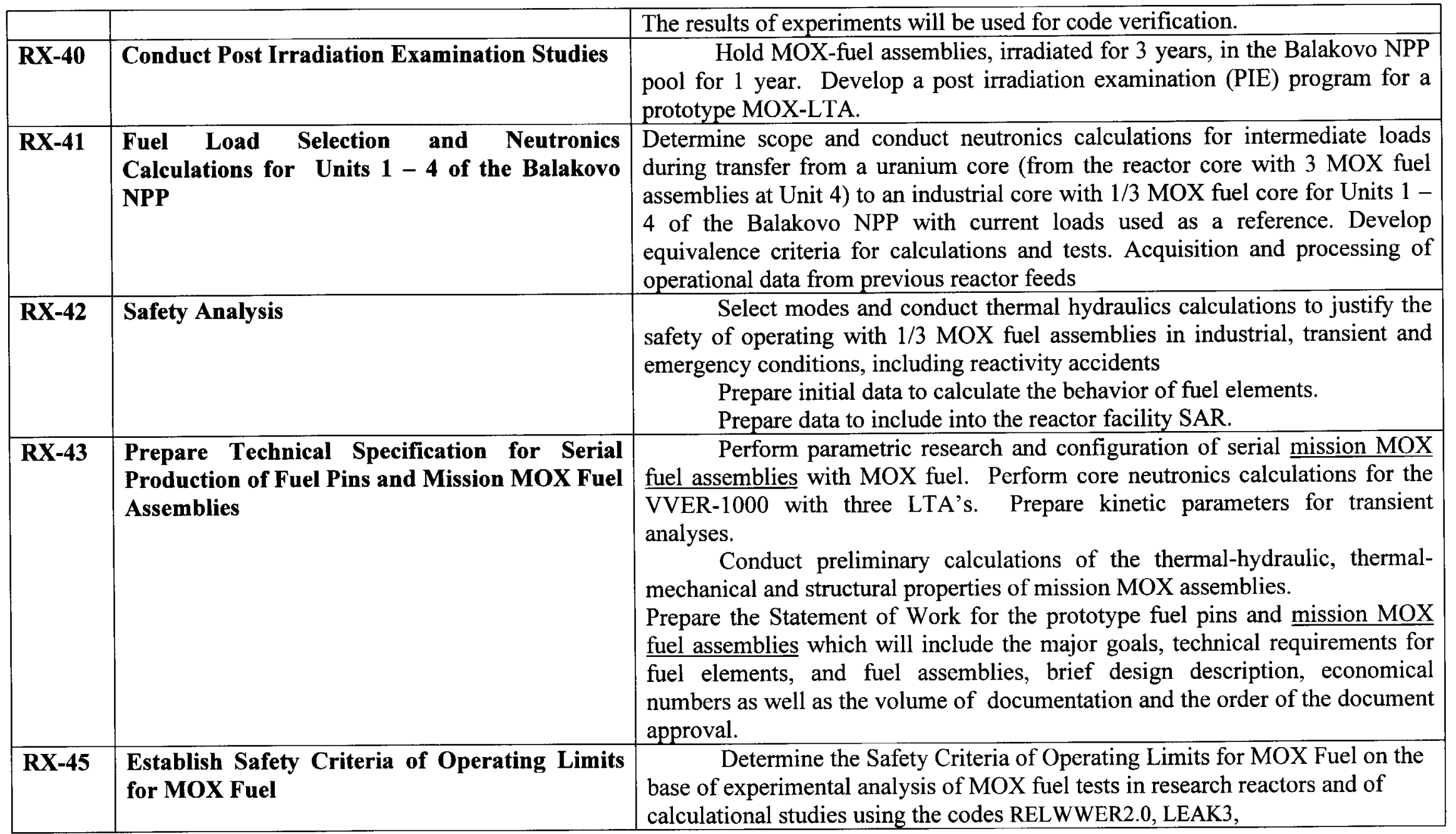


Russian Research Center "Kurchatov Inatturto"

Physics outlining steps necessary for insertion of the LTA, and operation using a 1/3 MOX loaded core

\begin{tabular}{|l|l|l|}
\hline RX-47 & $\begin{array}{l}\text { Evaluate/Analyze the Safety of the } \\
\text { Handling/Transfer/Operation Processes at a } \\
\text { NPP }\end{array}$ & $\begin{array}{l}\text { MELCOR,CONTAIN, VICTORIA, ORIGEN. } \\
\text { Develop a design of spent fuel container. } \\
\text { Develop a Statement of Work for calculating handling/transfer/process } \\
\text { operations with MOX fuel at the NPP. Calculate nuclear and radiation safety } \\
\text { during handling/transfer/process operations with fresh and spent fuel. Examine } \\
\text { the existing handling/transfer/process equipment from the standpoint of its } \\
\text { application for the mission MOX fuel. } \\
\text { Determine the nomenclature of the required new and upgraded } \\
\text { equipment and instruments. Analyze consequences of radiation accidents } \\
\text { resulting from handling mission MOX fuel. } \\
\text { Prepare and pass on initial data for analyzing available facilities and } \\
\text { equipment for the storage and transportation of mission MOX fuel. Determine } \\
\text { requirements for in-plant systems for reactor facilities with mission MOX fuel. } \\
\text { Prepare the data to be included into the Reactor Facility Safety Analysis } \\
\text { Report (SAR) of the Balakovo NPP. }\end{array}$ \\
\hline
\end{tabular}


Russian Rosearch Center "Kurchatov Insttute"

Physics outlining steps necessary for insertion of the LTA, and operation using a 1/3 MOX loaded core

\begin{tabular}{|c|c|c|}
\hline RX-49 & $\begin{array}{l}\text { Adjust, Validate and Certify the Codes for } \\
\text { Neutron Calculations and Fuel Pin Codes }\end{array}$ & $\begin{array}{l}\text { Adjust thermal mechanical and neutronics characteristics of mission } \\
\text { MOX fuel (including gaseous fission products, iodine and cesium yield from } \\
\text { fuel pellets and spatial distribution of isotopes in the pellets) based on the } \\
\text { results of reactor and post-reactor studies of capsules from the experimental fuel } \\
\text { elements at MIR and the BIGR reactors and the test mission MOX fuel } \\
\text { elements at Unit } 4 \text { of Balakovo NPP VVER reactor. The characteristics are } \\
\text { calculated using fuel elements codes and neutronics software programs. } \\
\text { Determine uncertainties in the characteristics of fuel elements and the } \\
\text { core. Correct the neutronics program based on the analysis of discrepancies } \\
\text { between the calculations and test results of irradiating mission MOX fuel } \\
\text { assemblies at the 4th Unit of the Balakovo NPP. } \\
\text { Estimation of documentation specification on verification and its } \\
\text { completion for the codes to be certified. } \\
\text { Prepare certification documentation for the fuel elements codes CTAPT } \\
\text { (START), PAITA (RAPTA) and } \text { QPEД (FRED) and if necessary for } \\
\text { MCU/ORIGEN-S, TBC-M (TVS-M), БИПP7-A (BIPR7-A), ПEPMAK-A } \\
\text { (PERMAK-A). Send the application to the Certification Commission under the } \\
\text { Science and Technology Center of GAN of the RF to obtain a certificate. }\end{array}$ \\
\hline RX-55 & $\begin{array}{l}\text { Develop an Addendum to the SAR for the } \\
\text { Reactor Operation Safety of Balakovo-4 } \\
\text { Reactor Unit with 1/3 MOX Core }\end{array}$ & $\begin{array}{l}\text { Introduce necessary changes to the SAR for Balakovo } 4 \text { that result from } \\
\text { modifications and the analysis of radiation consequences of accidents with } \\
\text { mission MOX fuel assemblies performed in RX-47. }\end{array}$ \\
\hline RX-57 & Personnel Training & $\begin{array}{l}\text { Provide procedural software to the NPP personnel to perform neutronics } \\
\text { calculations and conduct experimental research in the course of operations with } \\
\text { 1/3 MOX Core. Conduct training of the following personnel involved in the } \\
\text { operation of Unit } 4 \text { in context of operational documentation updates: } \\
\text { Transportation and processing operations; } \\
\text { Physicists and nuclear safety personnel; } \\
\text { Radiation safety personnel; } \\
\text { Security personnel; }\end{array}$ \\
\hline
\end{tabular}


Russian Research Center "Kurchatov Instituti"

Physics outlining steps necessary for insertion of the LTA, and operation using a 1/3 MOX loaded core

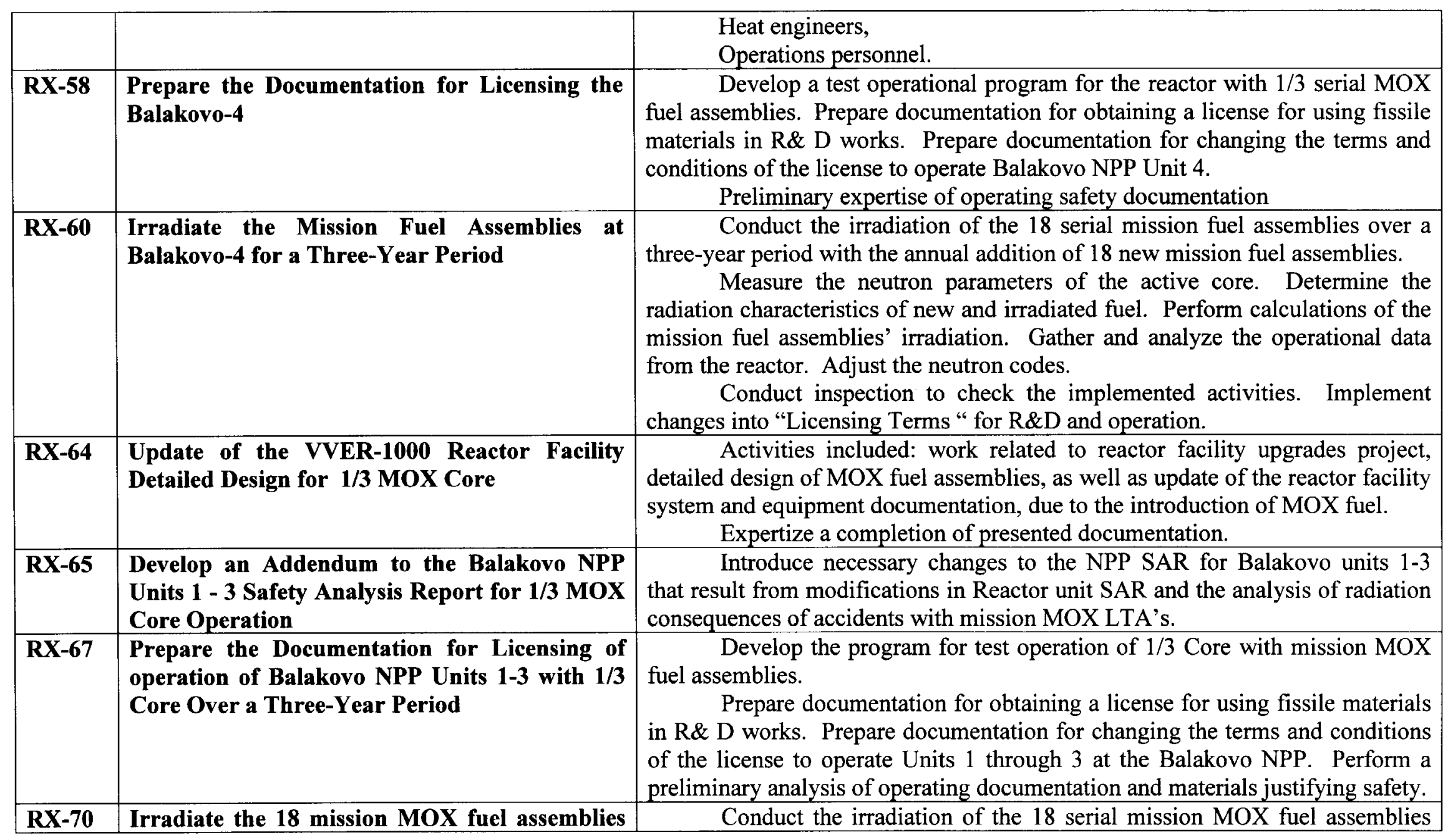




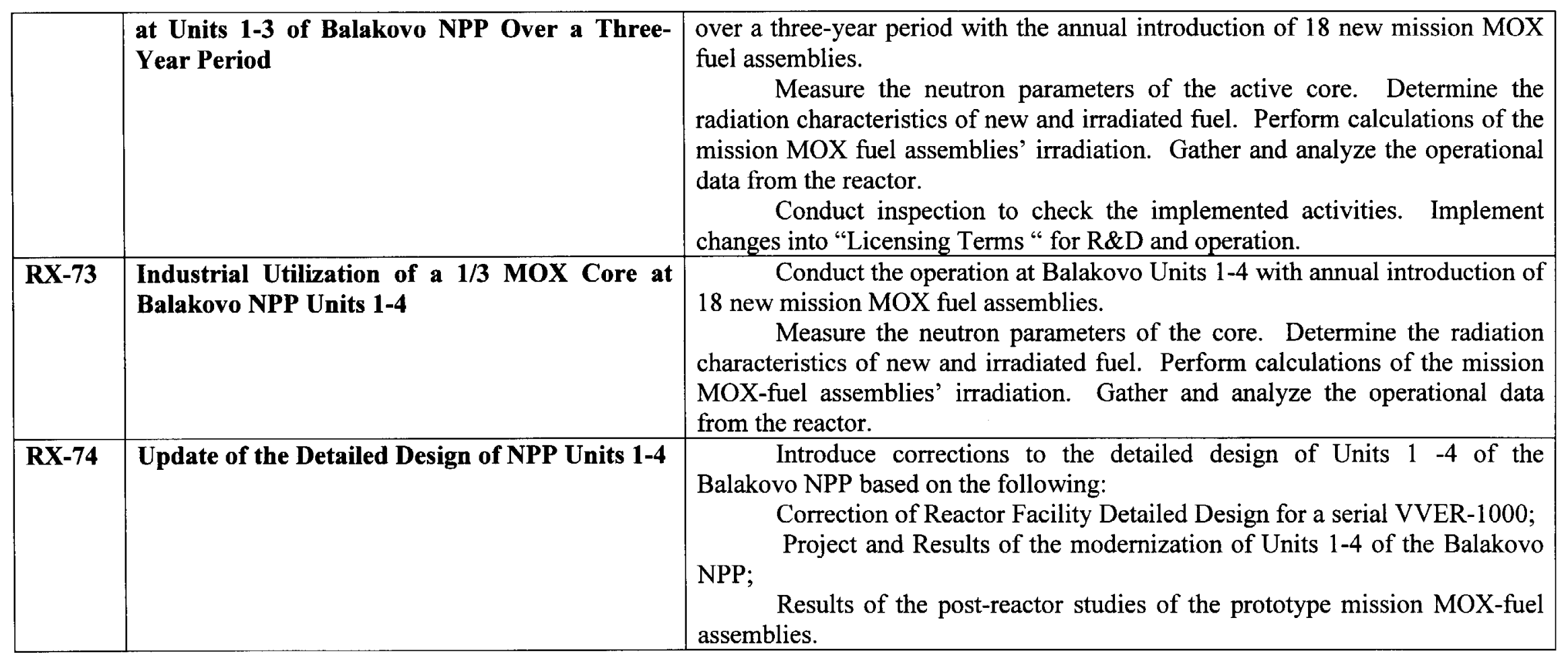


Russian Research Center "Kurchatov Inattute"

Physics outlining steps necessary for insertion of the LTA, and operation using a 1/3 MOX loaded core

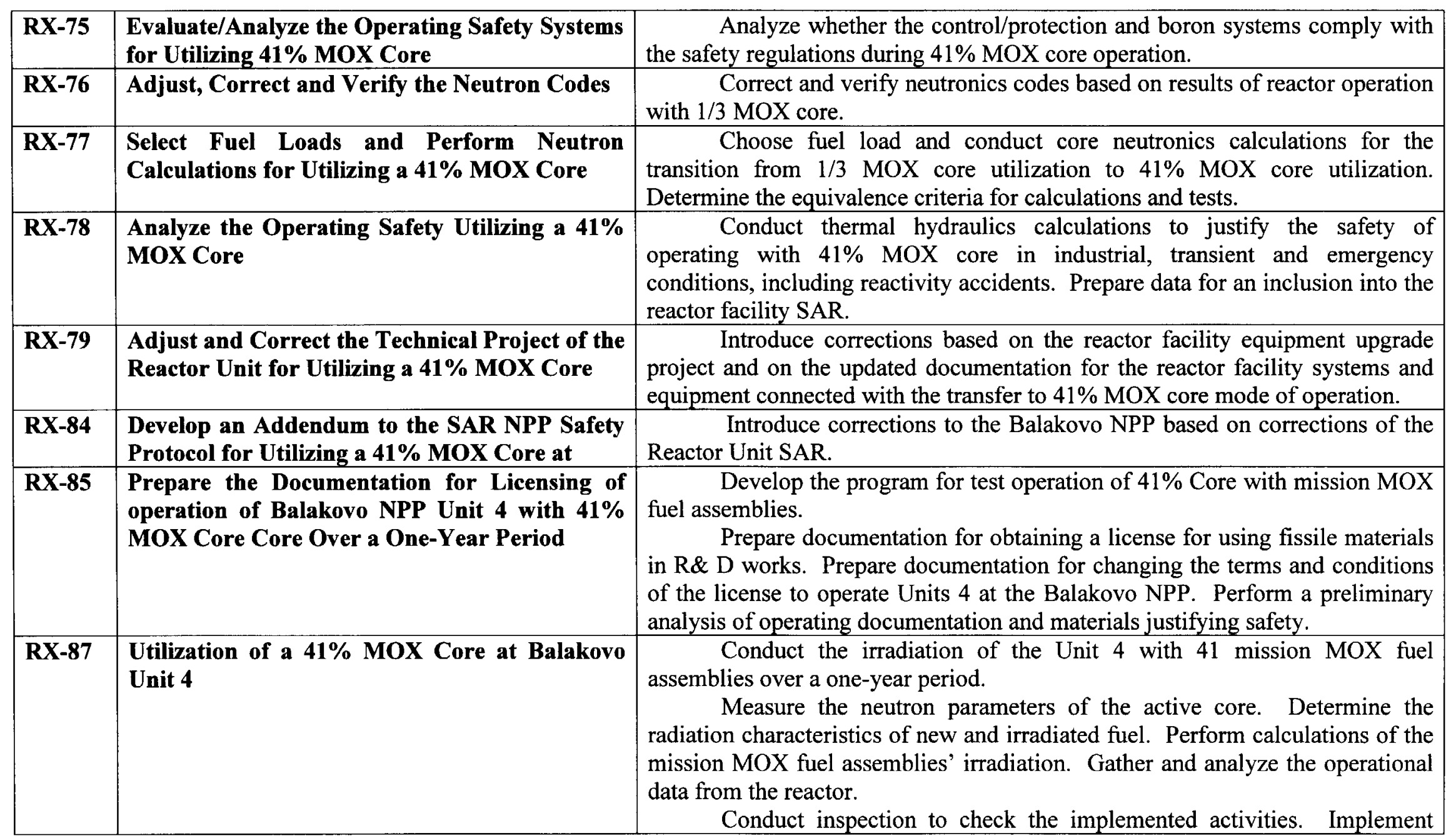


Russian Research Center "Kurchatov Instturto"

Physics outlining steps necessary for insertion of the LTA, and operation using a 1/3 MOX loaded core

\begin{tabular}{|l|l|l|}
\hline RX-88 & $\begin{array}{l}\text { Revise the Reactor Facility and NPP Detailed } \\
\text { Design for Utilizing a 41\% MOX Core }\end{array}$ & $\begin{array}{c}\text { changes into "Licensing Terms " for R\&D and operation. } \\
\text { Revise and verify the technical design for a Reactor facility and for a NPP } \\
\text { based the modernization of the control/protection and boron systems. } \\
\text { Expertise a completion of presented documentation }\end{array}$ \\
\hline RX-89 & $\begin{array}{l}\text { Prepare the Documentation for Licensing of } \\
\text { operation of Balakovo NPP Units with 41\% } \\
\text { MOX Core }\end{array}$ & $\begin{array}{l}\text { Prepare documentation for changing the terms and conditions of the } \\
\text { license to operate Balakovo NPP Units1-4 with 41\% MOX fuel. } \\
\text { Update the regulatory document "Nomenclature of Operational } \\
\text { the }\end{array}$ \\
$\begin{array}{l}\text { Reutronic Calculations and of Experiments for Fuel Loading of VVER 1000". } \\
\text { Perform a preliminary analysis of operating documentation and } \\
\text { materials justifying safety. }\end{array}$ \\
\hline
\end{tabular}


Russian Research Center "Kurchatov Institute"

Physics outlining steps necessary for insertion of the LTA, and operation using a 1/3 MOX loaded core

\section{Connection of FY2000 (KI-WR04RTP) items with Roadmap-level 2}

In the Table below the connection of KI-WR04RTP tasks of General Order 85B-99398V with Roadmap-level2 is presented.

\begin{tabular}{|l|l|l|}
\hline \multicolumn{1}{|c|}{ FY2000 } & \multicolumn{1}{|c|}{ Roadmap } & \multicolumn{1}{c|}{ Comments } \\
\hline $00-1$ & & Presented document \\
\hline $00-2$ & RX-12 & \\
\hline $00-3$ & RX-12 & \\
\hline $00-4$ & $\begin{array}{l}\text { RX-3, RX-11, } \\
\text { RX-43 }\end{array}$ & \\
\hline $00-5$ & RX-2 & \\
\hline $00-6$ & RX-9 & \\
\hline $00-7$ & RX-2, RX-9 & \\
\hline $00-8$ & RX-2 & \\
\hline $00-9$ & & Funding of business trips \\
\hline $00-10$ & RX-4 & \\
\hline $00-11$ & RX-2 & \\
\hline $00-12$ & RX-2 & \\
\hline
\end{tabular}




\section{Comments from ORNL staff on Overall Plan for Physics Outlining Steps Necessary for Insertion of the LTA and Operation Using a 1/3 MOX Loaded Core}

1. Page 4, last paragraph, fourth line from the end: "base" should be "basis."

2. Page 5, in some places in the report, the nomenclature "ROADMAP.level 2 " is used; elsewhere it is called "Roadmap-level 2." A consistent phrase should be used.

3. Page 6, last sentence in the third column: The sentence, "Modify the methodology on leak-proof check the fuel element cladding" appears to be misplaced. If not, more explanation is needed.

4. Page 7, third column, second sentence: "absorbents" should be "absorbers."

5. Page 9, third column, first sentence: suggest adding the phrase "for passport" after the word "application."

6. Page 10, third column, third row: MOX-LTA's should be MOX-LTAs.

7. Page 10, third column, fourth row, fifth line from the bottom: "reactions rate" should be "reaction rates."

8. Page 11, third column, first row, fifth line: BIPR7-A should be BIPR8-KN.

9. Page 12, third column, second row, third line: the hyphen (-) between MOX and LTA should be replaced with a space.

10. Page 12, third column, fifth row, fifth line: the commonly used American English expression is "thermal hydraulics." Various styles are used in this report.

11. Page 13, third column, second row, ninth line: "handling" should be "mishandling." Handling of the fuel should not lead to accidents, per se.

12. Page 16, third column, third row, next to last line: delete the hyphen between "MOX" and "fuel."

13. Page 17, third column, last row, first line: " 41 " should be " $41 \%$."

14. Page 18, comment on RX-91. It would assist American reviewers if data for earlier Balakovo cores could be released for computer program model development and calculation. 


\section{ORNL/SUB/00-85B99398V-1}

\section{INTERNAL DISTRIBUTION}
1-5. B. B. Bevard
6. R. Belles
7. J. J. Carbajo
8. M. D. DeHart
9. F. C. Difilippo
10. R. J. Ellis
11. S. E. Fisher
12-16. J. C. Gehin
17. S. R. Greene
18. R. F. Holdaway
19. D. T. Ingersoll

20. S. B. Ludwig

21. M. A. Kuliasha

22. G. E. Michaels

23. R. J. Moses

24. W. P. Poore III

25-29. R. T. Primm III

30. C. C. Southmayd

31. G. L. Yoder, Jr.

32-33. D. L. Williams

34. Central Research Library

35. ORNL Laboratory Records-RC

\section{EXTERNAL DISTRIBUTION}

36. M. L. Adams, Department of Nuclear Engineering, Texas A\&M University, Zachry 129, College Station, TX 77843

37. D. Alberstein, Los Alamos National Laboratory, MS-K551, P.O. Box 1663, Los Alamos, NM 87545

38. J. F. Baker, Office of Fissile Materials Disposition, U.S. Department of Energy, NN-63, 1000 Independence Avenue SW, Washington, DC 20585

39. J. B. Briggs, Idaho National Environmental and Engineering Laboratory, P.O. Box 1625-3855, Idaho Falls, ID 83415-3855

40. A. K. Caponiti, Office of Fissile Materials Disposition, U.S. Department of Energy, NN-63, 1000 Independence Avenue SW, Washington, DC 20585

41. N. Fletcher, Office of Fissile Materials Disposition, U.S. Department of Energy, NN-63, 1000 Independence Avenue SW, Washington DC 20585

42. K. Chidester, Los Alamos National Laboratory, MS-E502, P.O. Box 1663, Los Alamos, NM 87545

43. W. Danker, U.S. Department of Energy, NN-62, 1000 Independence Avenue SW, Washington, DC 20585

44. T. Gould, Lawrence Livermore National Laboratory, P.O. Box 808, MS-L186, Livermore, CA 94551

45. L. Jardine, Lawrence Livermore National Laboratory, P.O. Box 808, MS-L166, Livermore, CA 94551

46. A. Kalashnikov, Institute of Physics and Power Engineering, 1 Bondarenko Square, Obninsk, Kaluga Region, Russia 249020

47. J. O. Nulton, Office of Fissile Materials Disposition, U.S. Department of Energy, NN-61, 1000 Independence Avenue SW, Washington, DC 20585 
48. Dr. Stephen L. Passman, Booz-Allen \& Hamilton, 555 13th Street, NW, No. 480E, Washington, DC 20004

49-53. Dr. Alexander Pavlovitchev, Russian Research Center "Kurchatov Institute," Institute of Nuclear Reactors, VVER Division, VVER Physics Department, 123182, Kurchatov Square, 1, Moscow, Russia

54. K. L. Peddicord, Associate Vice Chancellor, Texas A\&M University, 120 Zachry, College Station, TX 77843-3133

55. F. Trumble, Westinghouse Savannah River Company, Building 730R, Room 3402, WSRC, Aiken, SC 29808

56. R. H. Clark, Duke/Cogema/Stone \& Webster, 400 South Tryon Street, WC-32G, P.O. Box 1004, Charlotte, NC 28202

57. S. Nesbit, Duke/Cogema/Stone \& Webster, 400 South Tryon Street, WC-32G, P.O. Box 1004, Charlotte, NC 28202

58. M. S. Chatterton, Office of Nuclear Reactor Regulation, MS O10B3, U.S. Nuclear Regulatory Commission, Washington, DC 20555-0001

59. R. W. Lee, Office of Nuclear Reactor Regulation, MS O10B3, U.S. Nuclear Regulatory Commission, Washington, DC 20555-0001

60. U. Shoop, Office of Nuclear Reactor Regulation, MS O10B3, U.S. Nuclear Regulatory Commission, Washington, DC 20555-0001

61. Nagao Ogawa; Director and General Manager; Plant Engineering Department; Nuclear Power Engineering Corporation; Shuwa-Kamiyacho Building, 2F; 3-13, 4-Chome Toranomon; Minato-Ku, Tokyo 105-0001, Japan

62. Dr. Kiyonori Aratani; Surplus Weapons Plutonium Disposition Group; International Cooperation and Nuclear Material Control Division; Japan Nuclear Cycle Development Institute; 4-49 Muramatsu, Tokai-mura, Naka-gun, Ibaraki-ken, Japan

63. E. Siskin, Office of Fissile Materials Disposition, U.S. Department of Energy, NN-60, 1000 Independence Avenue SW, Washington, DC 20585

64. Boris E. Volkov; Head of Division; EDO Gidropress; 21 Ordzhonikidze Street; Podolsk, Moscow District, Russia 142103 